\title{
Maturation of Eugenia pyriformis seeds under different hydric and thermal conditions
}

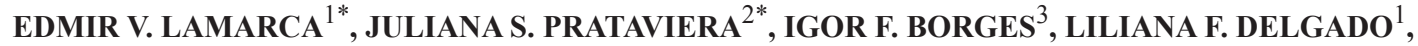 \\ CARMEN C. TEIXEIRA ${ }^{4}$, MARCELO B.P. DE CAMARGO ${ }^{5 *}$, JOSÉ M.R. FARIA ${ }^{6 *}$ and CLAUDIO J. BARBEDO ${ }^{7 *}$ \\ ${ }^{1}$ Programa de Pós-Graduação em Biodiversidade Vegetal e Meio Ambiente, Instituto de Botânica, \\ Av. Miguel Stéfano, 3687, 04301-012 São Paulo, SP, Brasil \\ ${ }^{2}$ Prataviera Consultoria, Rua Beira Mar, 8, Cumuruxatiba, 45983-000 Prado, BA, Brasil \\ ${ }^{3}$ Dow AgroSciences, Regulatory Sciences and Government Affairs, \\ Av. das Nações Unidas, 14171, $2^{\circ}$ andar, Torre Diamond, 04794-000 São Paulo, SP, Brasil \\ ${ }^{4}$ Programa de Pós-Graduação em Ciências Biológicas, Universidade Estadual Paulista/UNESP, \\ Instituto de Biociências, Distrito de Rubião Jr., s/n, 18618-970 Botucatu, SP, Brasil \\ ${ }^{5}$ Instituto Agronômico de Campinas, Centro de Ecofisiologia e Biofísica, \\ Av. Theodureto de Almeida Camargo, 1500, 13075-630 Campinas, SP, Brasil \\ ${ }^{6}$ Universidade Federal de Lavras, Departamento de Ciências Florestais, \\ Caixa Postal 3037, 37200-000 Lavras, MG, Brasil \\ ${ }^{7}$ Instituto de Botânica, Núcleo de Pesquisas em Sementes, \\ Av. Miguel Stéfano, 3687, 04301-012 São Paulo, SP, Brasil
}

Manuscript received on December 2, 2011; accepted for publication on February 1, 2012

\begin{abstract}
This study aims to analyze the maturation and dispersal of Eugenia pyriformis Cambess. seeds produced in different years, and the influence of variation in thermal and hydric environment on seed physical and physiological characteristics at dispersal. Fruits at different developmental stages were harvested in the city of São Paulo between 2003 and 2010, as well as in the cities of Campinas and Lavras, in 2009 and 2010 and analyzed for size and color. The seeds were extracted from the fruits and their dry mass, water content, germination and vigor were assessed. Results showed that seed maturation is unsynchronized to the maturation of the fruit, taking 45 days on average (430 growing degree-days), longer in rainy times or lower temperatures. Seeds with higher physiological quality were produced in rainy years and when the temperature range was larger. We concluded therefore that hydric and thermal environmental variations during development influence the maturation of Eugenia pyriformis seeds and are able to determine the formation cycle and the final seed quality.
\end{abstract}

Key words: dispersal, development, degree-day, rainfall, recalcitrants seeds.

\section{INTRODUCTION}

Among the environmental conditions that influence growth, production and quality of fruits and seeds, are the weather (represented by some meteorological

Correspondence to: Edmir Vicente Lamarca

E-mail: lamarcabio@ig.com.br

*CNPq Fellowship elements as rainfall and air temperature) (Reuther 1977, Pereira et al. 2002, Souza et al. 2004). In some perennial plants, the air temperature, represented by the concept of growing degree-day (GDD), influences the length of the reproductive cycle and is considered one of the most significant meteorological elements (Volpe et al. 2002, Petek 
et al. 2009, Fagundes et al. 2010) acting on the acquisition of some physical and physiological characteristics (Daws et al. 2004, 2006, Daws and Jensen 2011). However, some studies report that this thermal-dependence may be altered by rainfall, changing flowering and maturation periods (Volpe et al. 2002, Ribeiro et al. 2006, Petek et al. 2009), thus, showing the importance of analyzing these variables together.

The "uvaieira" tree (Eugenia pyriformis Cambess. - Myrtaceae) produces edible meaty yellow fruits (Oliveira et al. 2010). Its recalcitrant seeds (Delgado and Barbedo 2007) have been little studied regarding maturation, dispersal and physiology, making difficult technological development for plant production. In Eugenia species, great physical and physiological variation during fruit and seed development and maturation is observed (Silva et al. 2001, Pio et al. 2005, Avila et al. 2009, Cardoso and Lomônaco 2003, Borges et al. 2010, Braz and Mattos 2010, Lamarca et al. 2011). These variations show the adaptive ability of the genus to unpredictable, heterogeneous or transitional environments (Cardoso and Lomônaco 2003).

Recent studies with seeds of native species from Brazil verified that rainfall and air temperature can impact on water content and seed germination (Martins et al. 2009). However, among the Brazilian native species, there is little information that relates climatic conditions to seed maturation, dispersal and physiology. Therefore, knowledge of fruit and seed maturation of this species and its relationships with meteorological elements become important mechanisms to know the species behavior for its reproduction and adaptation. This knowledge can help predict the appropriate seed collection time to obtain seeds with high physiological quality as well as high quality seed production. This study aimed to characterize the maturation and dispersal of Eugenia pyriformis seeds and analyze the influence of hydric and thermal variations of the environment on these processes.

\section{MATERIALS AND METHODS}

Eugenia pyriformis Cambess. seeds were obtained from harvested fruits at the Instituto de Botânica

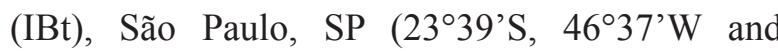
$785 \mathrm{~m}$ altitude), on Santa Elisa Farm of Instituto Agronômico (IAC), Campinas, SP (2252'S, $47^{\circ} 04^{\prime} \mathrm{W}$ and $645 \mathrm{~m}$ altitude), and at the city of Lavras, MG (21 ${ }^{\circ} 13^{\prime} \mathrm{S}, 44^{\circ} 58^{\prime} \mathrm{W}$ and $943 \mathrm{~m}$ altitude). The climatic classification of these three regions, according to Köppen, is Cwb, and Cwa and Cwa, respectively. The seeds were manually extracted and stored in perforated plastic bags in a cold chamber at $7^{\circ} \mathrm{C}$ until the beginning of the experiments, but no later than seven days (Barbedo et al. 1998, Andrade and Ferreira 2000).

The fruits and seeds were biometrically characterized for color, texture and size (longitudinal and transversal diameter in $\mathrm{mm}$ ) according to Silva et al. (2001). Seed water content and dry mass were also determined by drying at $103^{\circ} \mathrm{C}$ for 17 hours (Ista 1985). The results are presented in $\mathrm{g}$ of water/ $\mathrm{g}$ of dry mass (g.g $\left.{ }^{-1}\right)$ and g.seed ${ }^{-1}$, respectively.

The seeds were evaluated for germination using Germitest ${ }^{\circledR}$ paper which had been moistened until saturation (without excess) with two sheets for the base and one for the covering (Brasil 2009). The test was carried out in two chambers with $100 \%$ air relative humidity at a constant $25^{\circ} \mathrm{C}$ and continuous light (Delgado and Barbedo 2007). The germination assessments were done every 3 days for 70 days, and the seeds that had primary roots were recorded (for germinable seed calculation) as well as the ones that presented normal seedling production (for germination calculation); the results were presented in decimal $(\% / 100)$ and in percentage $(\%)$. In order to estimate vigor, the germination speed index (GSI) was calculated according to Maguire (1962).

Climatic data for the locations and periods that the fruits were produced were obtained from automatic weather stations installed close to the harvest areas. Daily data of temperature and 
rainfall $(\mathrm{mm})$ were collected between flowering and harvest and were used to calculate respectively: the growing degree-day (GDD, ${ }^{\circ} \mathrm{C}$ day), according to the equations proposed by Villa Nova et al. (1972), considering $10^{\circ} \mathrm{C}$ as base temperature (Pedro Junior et al. 1977); and accumulated rainfall $(\mathrm{mm})$. Sequential water balance was also calculated with rainfall data using the model proposed by Thornthwaite and Mather (1955), in descending scale level with available water capacity (AWC) of $125 \mathrm{~mm}$ (Leivas et al. 2006, Rolim et al. 2007).

In a first experiment, aiming to characterize fruits and seeds at different maturation stages as well as recently dispersed ones, anthesis flowers of E. pyriformis matrices located at IBt were marked during the period of maximum flowering. Fruits were collected at different days after anthesis (DAA), directly from the tree. Collecting dates were determined based on the visual characteristics of fruit development and maturation like color and texture, established in previous studies. Thus, fruits obtained from three maturation stages were: stage I, characterized by a green color pericarp with visible signs of color changing into yellow; stage II with a whole light yellow pericarp; stage III, the whole pericarp is golden yellow. In addition, fruits with visual characteristics similar to the ones of stage III were directly collected from the ground soon after dispersal, but not after 24 hours, and called recently dispersed fruits. As soon as these stages were identified, a single collection was done and the fruits were separated according to their visual and dispersal characteristics described as follow. The seeds from all these collections were evaluated for their water content, dry mass content, germination and vigor as described before.

In a second experiment, aiming to analyze the influence of environmental conditions on the seed characteristics at fruit dispersal time, recently dispersed fruits were collected according to the previous experiment characterizing matrices located at IAC and in Lavras from 2009 to 2010, and at IBt in 2003, 2004, 2005, 2006, 2009 and 2010. In order to do that, anthesis flowers of E. pyriformis matrices were marked in the species maximum flowering period and the fruits were collected immediately after their dispersal. The seeds from these fruits were also evaluated for their water content, dry mass content, germination and vigor.

The experimental design for all experiments was completely randomized with four replications of 15 seeds. The obtained data were submitted to variance analysis (F test) at 5\% probability. When pertinent, the averages were compared using Tukey's test also considering a reliability level of 5\% (Santana and Ranal 2004).

\section{RESULTS AND DISCUSSION}

In 2003, IBt fruit sorting into sizes showed that the fruits in stages II and III were bigger, predominantly from 26 to $30 \mathrm{~mm}$, whereas the ones from 21 to $25 \mathrm{~mm}$ were predominantly in stage I and recently dispersed (Fig. 1). However, it was observed that fruit growth occurred until stage II, that is, until 37 DAA (a total of 379 GDD), only 3 days after stage I (34 DAA, totalizing 343 GDD). Although keeping the fruits some more days linked to the mother plant and accumulating more growing degree-days (40 DAA, 410 GDD), there was no increase in size. However, the decrease of recently dispersed fruit size probably occurred due to water loss after their detachment from the mother plant at 43 DAA (437 GDD).

The average size of seeds at different stages presented a small variation. The fruit seeds of stage I had an average of $9 \mathrm{~mm}$ for longitudinal diameters and $10 \mathrm{~mm}$ for transversal diameters. These dimensions were, respectively, 10 and $10 \mathrm{~mm}$ for seeds from fruits of stage II. Seeds from fruits of stage III and seeds recently dispersed showed $8 \mathrm{~mm}$ for longitudinal diameter and $9 \mathrm{~mm}$ for transversal diameter. However, for the frequency distribution of size categories of seeds from fruits obtained in a single collection, the seeds in stages I and II were among the biggest, predominantly from 11 to 15 $\mathrm{mm}$ whereas the ones from fruits in stage III and 

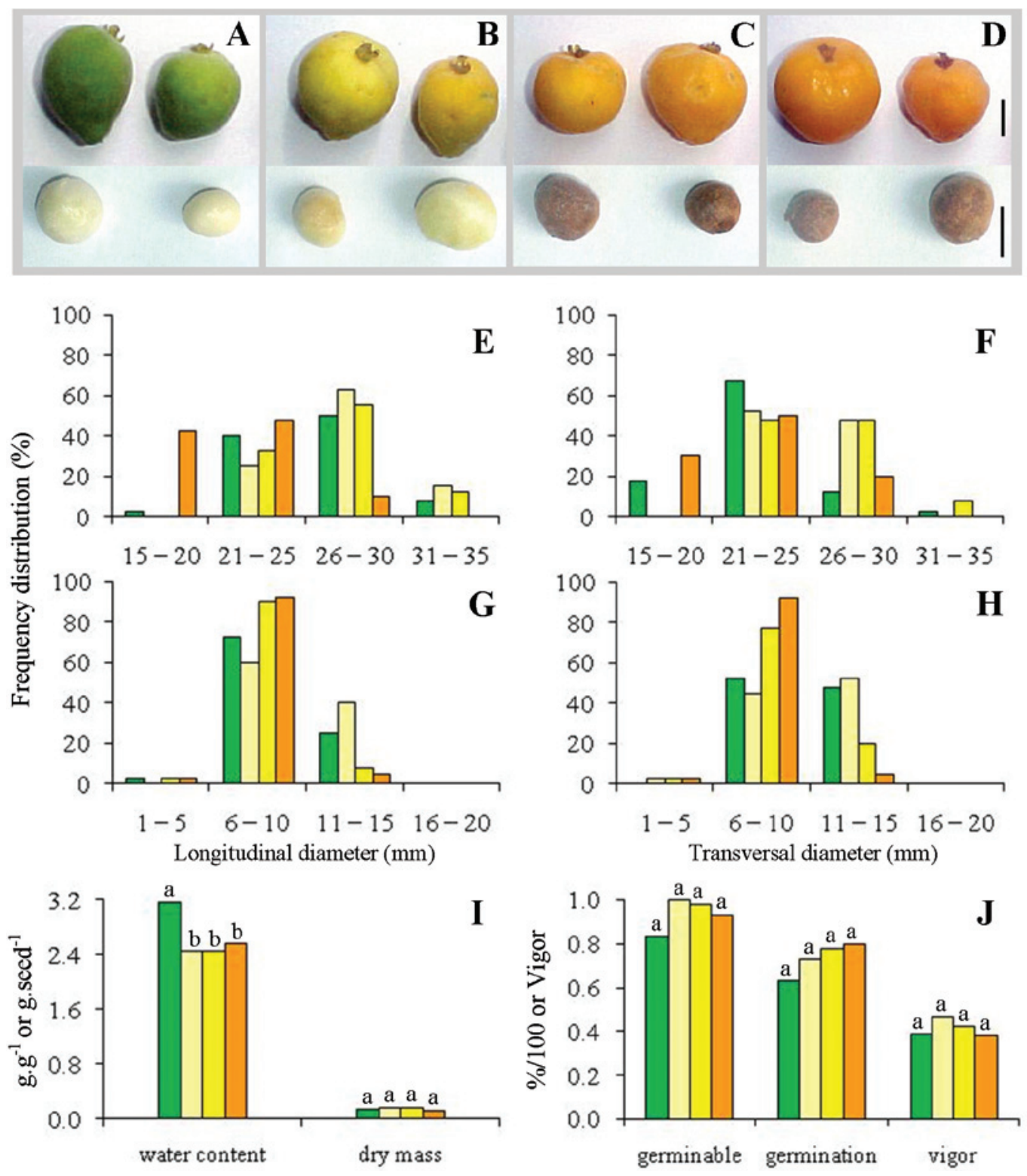

Fig. 1 - Physical and physiological characteristics of maturity stages of fruits and seeds of E. pyriformis harvested in the city of São Paulo. A to D, maturity stages of fruits and seeds: A, Stage I, 34 days after anthesis (DAA); B, Stage II, (37 DAA); C, Stage III (40 DAA); D, recently dispersed (43 DAA). E to H, frequency distribution of fruits and seeds length (mm): E, fruit longitudinal diameter; F, fruit transversal diameter; G, seeds longitudinal diameter; H, seeds transversal diameter. I, water content (g.g $\left.{ }^{-1}\right)$ and content of dry mass (g.seed $\left.{ }^{-1}\right)$ of seeds; J, germinable seeds, germination (\%/100) and vigor (GSI). Green columns, stage I; light yellow columns, stage II; golden yellow columns, stage III and orange columns, recently dispersed. Means followed by the same letter did not differ by Tukey's test at $5 \%$. Scale $1 \mathrm{~cm}$.

recently dispersed fruits were predominantly from 6 to $10 \mathrm{~mm}$ (Fig. 1). The highest water content could justify the bigger size of seeds from fruits of stage I, but not the ones from stage II (Fig. 1I). Considering that the dry mass content, the seed germinative capacity and vigor of fruits from all stages did not present differences (Fig. 1I and 1J), it is possible to conclud that even immature fruits can contain seeds with completely developed physiological characteristics. Nevertheless, the external visual 


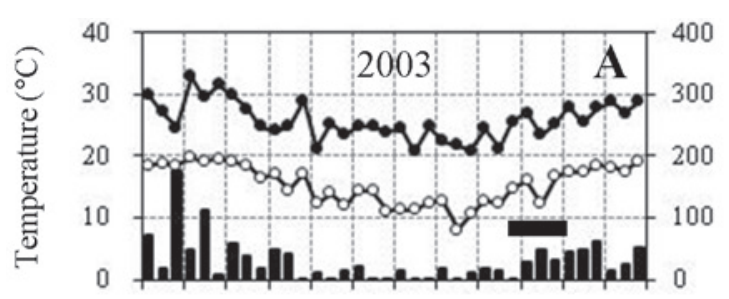

Jan Feb Mar AprMayJun Jul Aug Sep OctNovDec

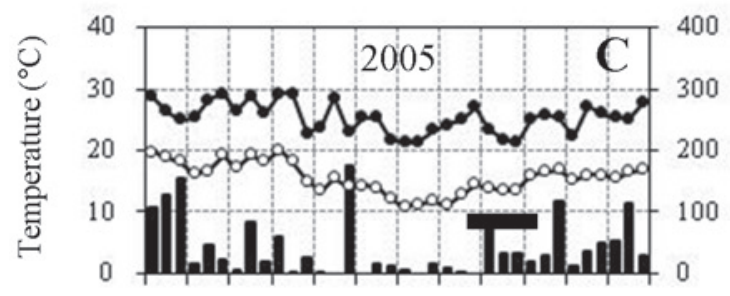

Jan Feb MarAprMay Jun Jul AugSep OctNov Dec

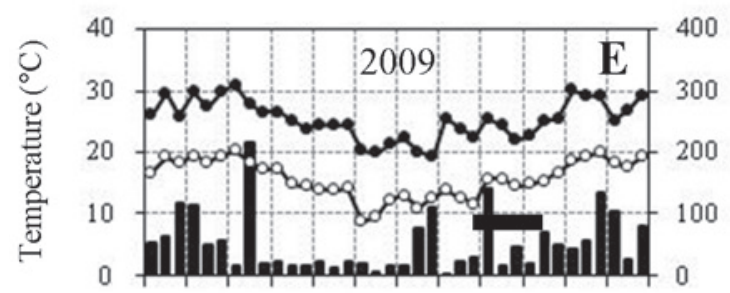

Jan Feb MarAprMayJun Jul Aug Sep Oct Nov Dec

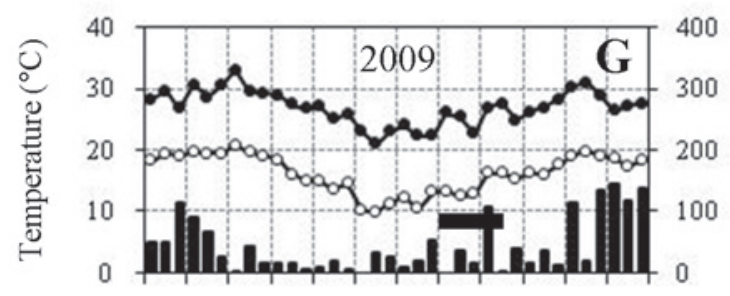

Jan Feb MarAprMay Jun Jul AugSep OctNov Dec

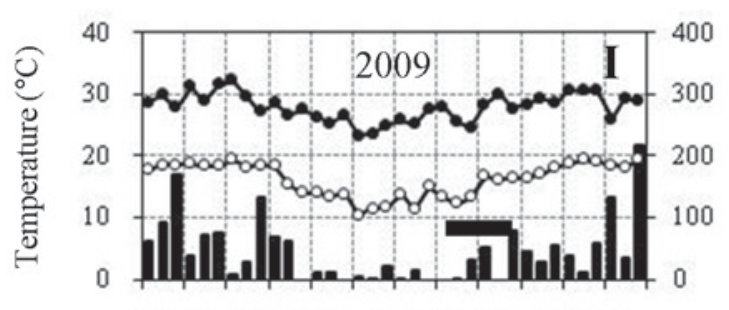

Jan Feb Mar A prMayJun Jul Auz Sep Oct NovDec

Period (month)

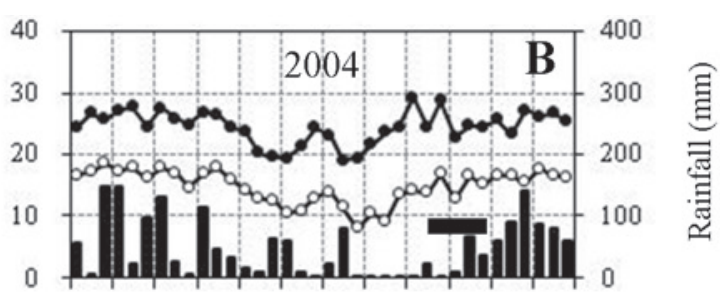

Jan Feb Mar AprMay Jun Jul Aug Sep Oct NovDec

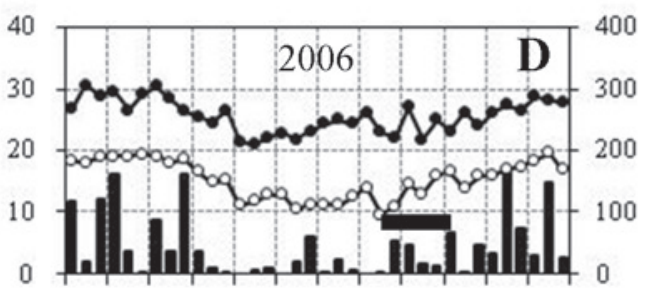

Jan Feb MarAprMay hun Jul AugSep OctNovDec

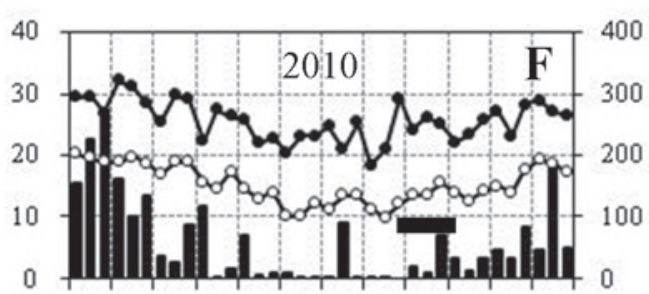

Jan Feb MarAprMayJun Jul AugSep Oct Nov Dec

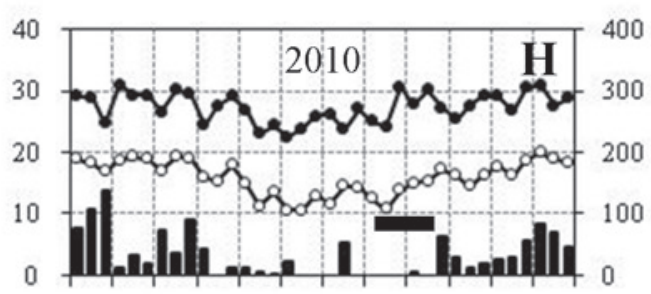

Jan Feb MarAprMayhun Jul Aug Sep Oct Nov Dec

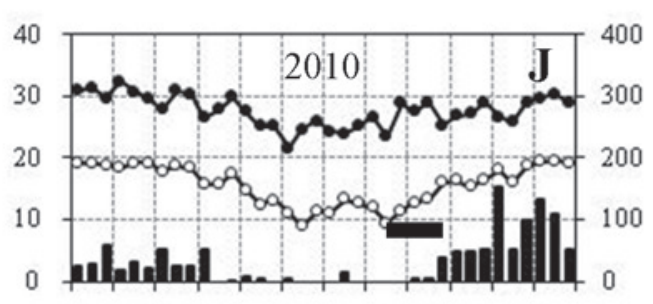

Jan Feb MarAprMayjun Jul AugSep OctNovDec

Period (month)

Fig. 2 - Meteorological data in the regions of São Paulo (A to F), Campinas ( $\mathrm{G}$ and H) and Lavras (I and J), at a decendial scale from 2003 to 2010, years of harvest of fruits of Eugenia pyriformis: maximum temperature (closed circle), minimum temperature (open circle), rainfall (black columns) and period between flowering and harvest of fruits (black bars).

characteristics of seeds changed. The seeds of fruits from stages I and II presented smooth surface and milky white, and greenish white color, respectively. On the other hand, the seeds of fruits from stage III and recently dispersed fruits presented light brown color and rough wrinkled surface (Fig. 1A to D).

The size variation of E. pyriformis seeds between the maturation stages may have occurred 


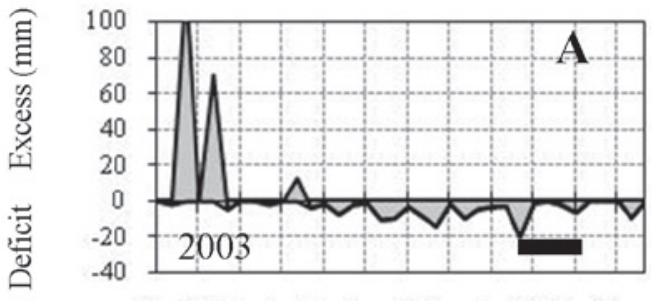

Jan Feb MarApr MayJun Jul Aug Sep Oct NovDec

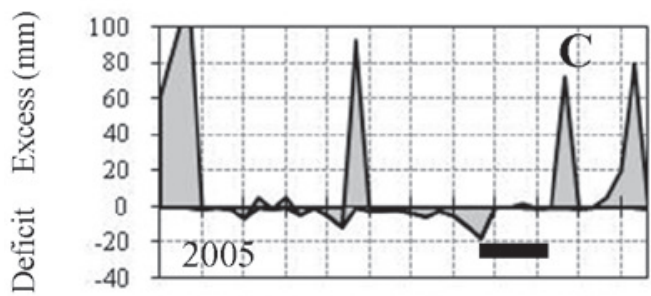

Jan Feb Mar AprMay hun hul AugSep OctNov Dec

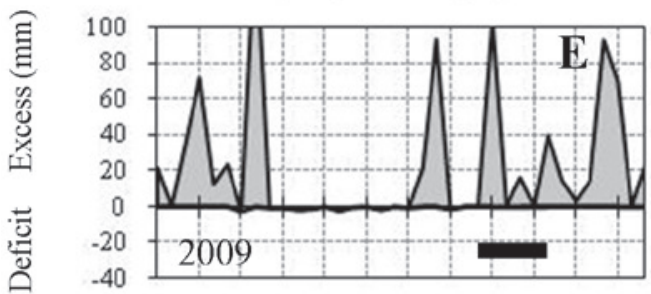

Jan Feb Mar AprMay hun Jul AugSep OctNov Dec

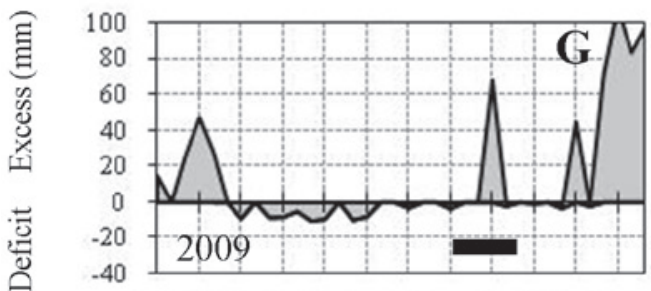

Jan Feb Mar AprMay hun Jul AugSep OctNov Dec

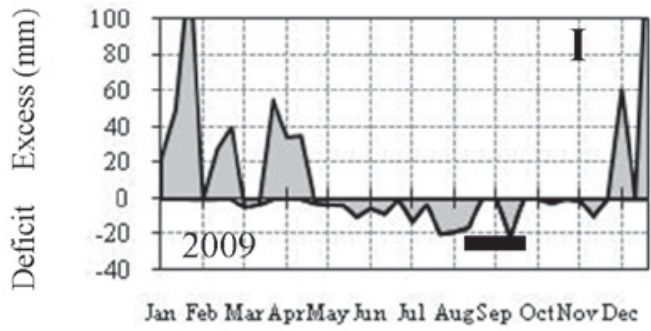

Period (month)

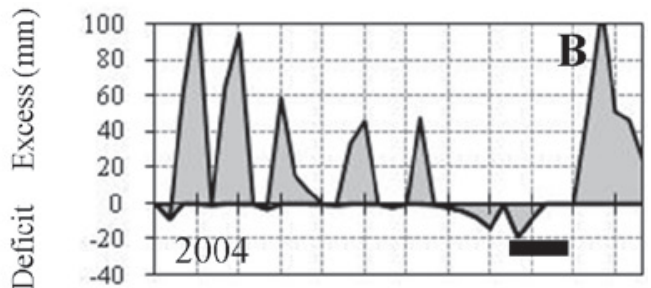

Jan Feb Mar AprMay Jun Jul AugSep OctNov Dec

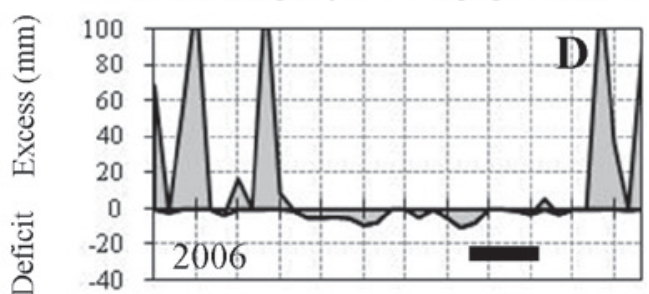

Jan Feb Mar AprMay Jun Jul AugSep Oct Nov Dec

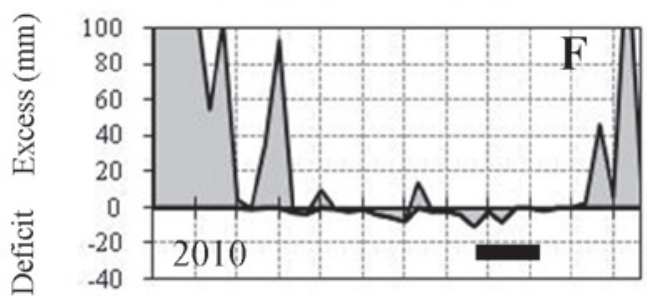

Jan Feb Mar AprMay hun Jul AugSep Oct Nov Dec

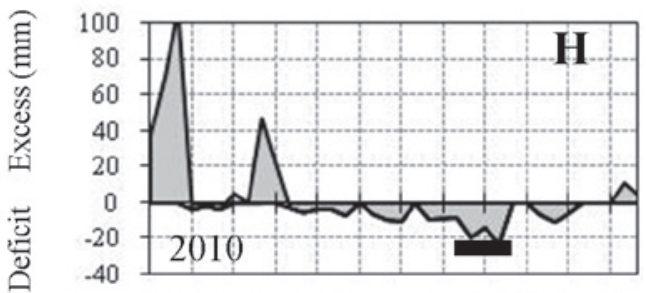

Jan Feb Mar AprMay Jun Jul Aug Sep Oct Nov Dec

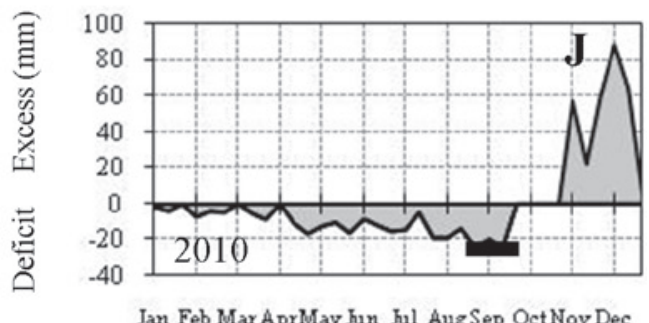

Period (month)

Fig. 3 - Sequential water balance in the regions of São Paulo (A to F), Campinas (G and H) and Lavras (I and J), from 2003 to 2010, years of harvest of fruits of Eugenia pyriformis: Black bars show period between flowering and harvest of fruits.

because of the meteorological variables of the formation environment. Considering that all fruits from all stages were collected on the same day (Nov. $11,2003)$, the smallest seed size of fruits from stage III and recently dispersed fruits may be related to processes that happened in the initial phases of seed development. The corresponding flowering of these fruits started in low rainfall periods (third tenday period of September, 2003, Fig. 2A) whereas fruit flowering of stages I and II started in rainy 
TABLE I

Phenological period (flowering and harvest of fruits) of fruits of Eugenia pyriformis, harvested in the region of São Paulo throughout the years of 2003, 2004, 2005, 2006, 2009 and 2010, and in Campinas and Lavras throughout the years of 2009 and 2010. Duration of phenologic cycle, meteorological data recorded during those periods (minimum and maximum absolute temperature, growing degree-day and accumulated rain) and physical and physiological characteristics of seeds harvested (water and dry mass content, germinable seeds, germination and vigor). Means followed by the same letter (from "a" to "f”) did not differ by Tukey's test at $5 \%$. IBt: Instituto de Botânica de São Paulo; IAC: Instituto Agronômico de Campinas ; GSI: Germination Speed Index.

\begin{tabular}{|c|c|c|c|c|c|c|c|c|c|}
\hline $\begin{array}{c}\text { Region of harvested } \\
\text { and phenological } \\
\text { period }\end{array}$ & $\begin{array}{l}\text { Cycles } \\
\text { (days) }\end{array}$ & $\begin{array}{c}\text { Min e Max } \\
\left({ }^{\circ} \mathrm{C}\right)\end{array}$ & $\begin{array}{c}\text { Degree-day } \\
\left({ }^{\circ} \mathrm{C} \text { day }\right)\end{array}$ & $\begin{array}{l}\text { Rain } \\
(\mathrm{mm})\end{array}$ & $\begin{array}{l}\text { Water content } \\
\qquad\left(\mathrm{g} \cdot \mathrm{g}^{-1}\right)\end{array}$ & $\begin{array}{l}\text { Dry mass } \\
\left(\mathrm{g} \mathrm{seed}^{-1}\right)\end{array}$ & $\begin{array}{c}\text { Germinable } \\
(\%)\end{array}$ & $\begin{array}{c}\text { Germination } \\
(\%)\end{array}$ & $\begin{array}{l}\text { Vigor } \\
\text { (GSI) }\end{array}$ \\
\hline $\begin{array}{c}\text { IBt, São Paulo } \\
22 / 09 / 03-04 / 11 / 03\end{array}$ & 43 & $9-34$ & 437 & 116.0 & $2.54 \mathrm{a}$ & $0.119 \mathrm{f}$ & $93 \mathrm{a}$ & 80 bcde & $0.379 \mathrm{~d}$ \\
\hline $\begin{array}{c}\text { IBt, São Paulo } \\
17 / 09 / 04-29 / 10 / 04\end{array}$ & 42 & $8-34$ & 432 & 128.5 & $2.04 \mathrm{bc}$ & 0.195 ef & $93 \mathrm{a}$ & 90 abcd & $0.401 \mathrm{~d}$ \\
\hline $\begin{array}{c}\text { IBt, São Paulo } \\
26 / 08 / 05-11 / 10 / 05\end{array}$ & 46 & $9-32$ & 416 & 161.2 & $1.85 \mathrm{bcd}$ & $0.201 \mathrm{ef}$ & $100 \mathrm{a}$ & $83 \mathrm{abcd}$ & $0.437 \mathrm{~d}$ \\
\hline $\begin{array}{c}\text { IBt, São Paulo } \\
17 / 08 / 06-06 / 10 / 06\end{array}$ & 50 & $4-34$ & 416 & 126.0 & $1.99 \mathrm{bc}$ & $0.259 \mathrm{de}$ & $97 \mathrm{a}$ & $92 \mathrm{abc}$ & $0.423 \mathrm{~d}$ \\
\hline $\begin{array}{c}\text { IBt, São Paulo } \\
25 / 08 / 09-12 / 10 / 09\end{array}$ & 48 & $9-32$ & 458 & 232.1 & $2.17 \mathrm{ab}$ & $0.192 \mathrm{ef}$ & $93 \mathrm{a}$ & 78 cde & $0.732 \mathrm{c}$ \\
\hline $\begin{array}{c}\text { IBt, São Paulo } \\
26 / 08 / 10-09 / 10 / 10\end{array}$ & 44 & $11-32$ & 428 & 128.8 & $1.82 \mathrm{bcd}$ & $0.221 \mathrm{de}$ & $70 \mathrm{~b}$ & $63 \mathrm{e}$ & $0.671 \mathrm{c}$ \\
\hline $\begin{array}{c}\text { IAC, Campinas } \\
01 / 08 / 09-18 / 09 / 09\end{array}$ & 48 & $10-32$ & 479 & 162.7 & $1.58 \mathrm{cde}$ & $0.311 \mathrm{~d}$ & $93 \mathrm{a}$ & $73 \mathrm{de}$ & $0.805 \mathrm{bc}$ \\
\hline $\begin{array}{c}\text { IAC, Campinas } \\
10 / 08 / 10-19 / 09 / 10\end{array}$ & 40 & $8-34$ & 451 & 6.3 & $1.25 \mathrm{e}$ & $0.479 \mathrm{c}$ & $93 \mathrm{a}$ & 92 abcd & $0.997 \mathrm{ab}$ \\
\hline $\begin{array}{c}\text { Lavras } \\
09 / 08 / 09-23 / 09 / 09\end{array}$ & 45 & $10-32$ & 495 & 175.4 & $1.53 \mathrm{de}$ & $0.591 \mathrm{~b}$ & $100 \mathrm{a}$ & $98 \mathrm{ab}$ & $0.948 \mathrm{ab}$ \\
\hline $\begin{array}{c}\text { Lavras } \\
15 / 08 / 10-25 / 09 / 10\end{array}$ & 41 & $7-33$ & 417 & 24.2 & $1.15 \mathrm{e}$ & $0.802 \mathrm{a}$ & $100 \mathrm{a}$ & $100 \mathrm{a}$ & $1.110 \mathrm{a}$ \\
\hline $\begin{array}{l}\text { Coefficient of } \\
\text { variation }(\%)\end{array}$ & & & & & 10.414 & 12.040 & 6.066 & 9.066 & 12.534 \\
\hline
\end{tabular}

periods (first ten-day period of October). Thus, the seeds of fruits from stage III and recently dispersed fruits underwent water deficit in the beginning of their development for 8 and 5 days, respectively (Fig. 3A), which may have resulted in the smaller final size. This behavior is similar to that observed in coffee fruits (Coffea arabica L.) over which the water deficit during the initial development stages (green fruit) accelerated the next stages and resulted in a higher percentage of void beans (Camargo and Camargo 2001). However, smaller sized Eugenia pyriformis seeds did not present physiological differences when compared to the bigger ones.
Microclimatic variations during the fruit formation influenced the physical characteristics of $E$. pyriformis seeds as well as the length of maturation period and dispersal moment. In general, it is noticed that the flowering commenced soon after low air temperature periods, and the fruit dispersal occurred in rainy periods. When compared to E. pyriformis formation periods of different years, it is observed that the seed final dry mass and the maturation and dispersal cycle presented a close relationship with temperature data (mainly the minimum one), water deficit and temperature range. The seeds from IAC, for example, were dispersed in 2009 with high water 

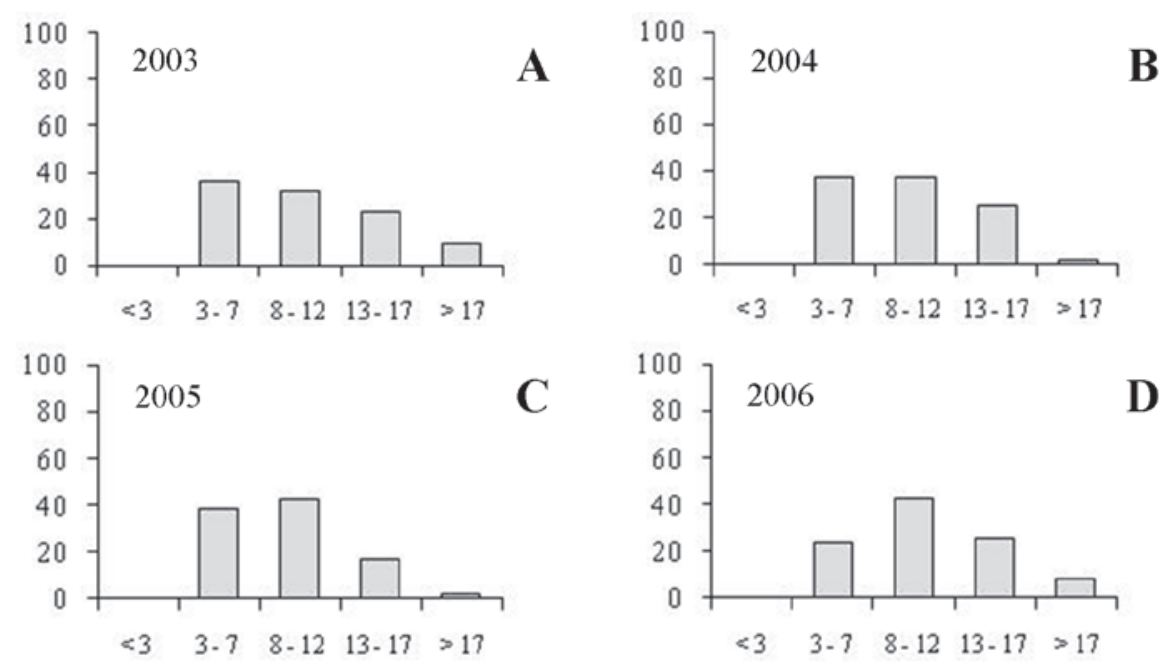

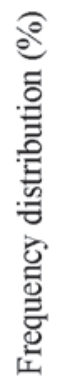

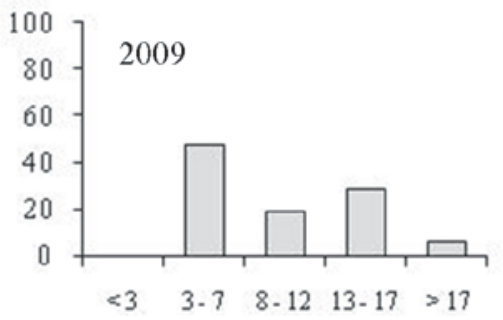

$\mathbf{E}$
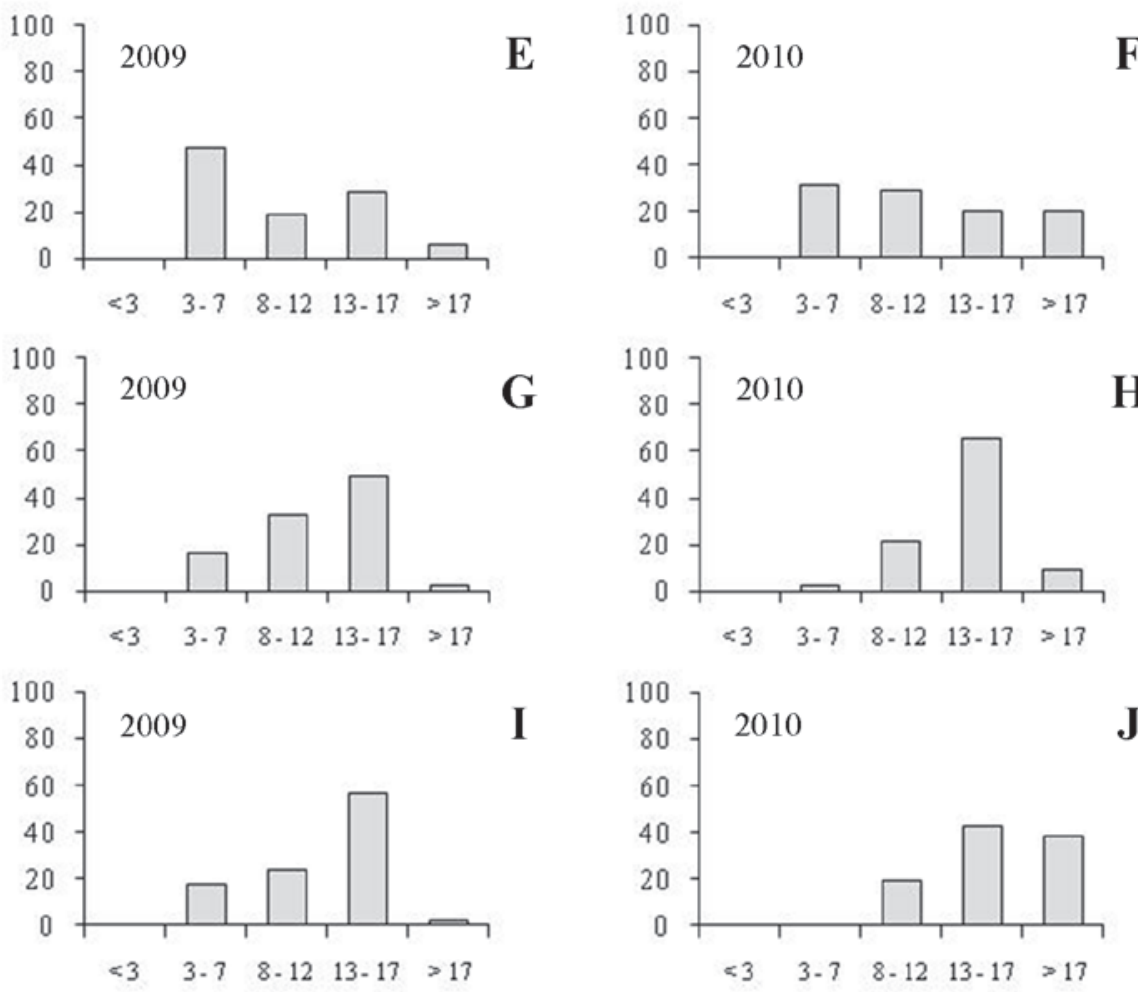

Temperature range $\left({ }^{\circ} \mathrm{C}\right)$

Temperature range $\left({ }^{\circ} \mathrm{C}\right)$

Fig. 4 - Frequency distribution of temperature range in the regions of São Paulo (A to F), Campinas (G and H) and Lavras (I and J), from 2003 to 2010, during the formation of fruit of Eugenia pyriformis.

contents and a smaller amount of dry mass than in 2010, but without differences in the germinative capacity and vigor (Table I). Such a difference may be related to a greater water deficit (Fig. 3) and a lower rainfall (Fig. 2) in 2010, reducing the cycle into
8 days (Table I). Similar results were observed in the seeds from Lavras (Table I and Fig. 2 and 3). The accumulation of dry mass in the seeds was influenced by the temperature range (Fig. 4), smaller in 2009 for both locations, resulting in smaller accumulation 
even in a longer cycle. Considering the results obtained at both sites in 2009 and 2010, apparently the biggest accumulation of dry mass occurred when the temperature range was higher than $12^{\circ} \mathrm{C}$, mainly if higher than $17^{\circ} \mathrm{C}$ (Table I and Fig. 4).

Regarding Eugenia pyriformis seeds produced at IBt from 2003 to 2010, in contrast to IAC and Lavras, the highest temperature range frequencies were never superior to $12^{\circ} \mathrm{C}$. These seeds always had less reserve accumulation rates as opposed to the ones obtained at the other two sites, reinforcing the idea that the highest reserve accumulation for these seeds occurs at a temperature range superior to $12^{\circ} \mathrm{C}$. However, the greatest dry mass accumulation did not necessarily result in better physiological quality of these seeds. In 2010, for example, although the seeds accumulated dry mass similar to the seeds formed in other years (probably guaranteed by the temperature range), their physiological quality was the lowest one, with low values of germinable seeds, germination and vigor (Table I). This lower physiological quality may be related to the higher water deficit (Fig. 3) and lower rainfall frequency (Fig. 2 and Table I). On the other hand, seeds produced in 2009 that did not undergo water deficit during the whole cycle (Fig. 3) and presented high physiological quality even with the smallest accumulation of dry mass compared to the ones from IAC or Lavras. Similarly to what was observed in Lavras and IAC, at IBt the seed production cycle was shorter ( 42 to 44 days, Table I) when the water deficit was higher (2003, 2004 and 2010, Fig. 3).

By analysing the regime of weather factors, it was verified that the accumulation of growing degree-day until the fruit dispersal moment can vary because of water balance and low temperature frequency. Thus, in the years with higher water deficit, i.e., in Lavras and IAC in 2010, the seed maturation period was shorter and with a smaller GDD (Fig. 2 and 3 and Table I), but the seeds were apparently dispersed more mature (Table I). The same occurred at IBt, under a higher water deficit and shorter cycle (Fig. 3 and Table I); however, when there was no water deficit (2009, Fig. 3), the maturation cycle and the accumulation of GDD were greater (Table I). However, in 2006, low temperatures in the beginning of the cycle (Fig. 2) seem to be related to the delay of the fruit dispersal moment and to the smallest accumulation of GDD. Meteorological data also showed that the hydric conditions of the environment influence the water content of seeds when they are dispersed (Fig. 3 and Table I), as observed in Euterpe edulis Mart. seeds (Martins et al. 2009).

The obtained results for the different regions and seasons showed that while the seeds are not dispersed, physical and physiological changes keep on occurring, and they may continue proportionally to the length of maturation period and/or the accumulation of GDD. This period is influenced by air temperature as observed in coffee (Coffea arabica L.) and orange (Citrus spp.) fruits (Volpe et al. 2002, Pezzopane et al. 2003). But apparently for E. pyriformis, the water deficit may have a bigger influence. Under sufficient water availability, the accumulation of GDD seems to influence the physiological quality of seeds. Studies related to seed development and maturation of perennial species from temperate climate with air temperature, represented by growing degree-day, showed that dry matter content, water content, germination and desiccation tolerance are influenced by this variable (Daws et al. 2004, 2006). Recent studies showed that seeds of different species of Eugenia produced in the same region may have thermal-dependence similar to germination than the seeds of the same species produced in different regions (Lamarca et al. 2011).

The influence of the environmental hydric conditions on Eugenia seed germination and development was shown by Braz and Mattos (2010). These results associated to the present study make evident that the environment can shape the seed behavior, depicting the possible capability of this genus that comprises species to survive in several environments. Thus, the characterization of the 
thermal-dependence for maturation and dispersal, although influenced by the water availability, enables the description of the physiological maturity state of E. pyriformis seeds as well as their physical and physiological maturity, showing that these characteristics can be influenced by the environmental hydric and thermal variables during this formation.

Air temperature greatly influences the seed physiological quality and germinative behavior (Daws et al. 2004, 2006, Lamarca et al. 2011). However, for E. pyriformis seeds, the air temperature influence represented by GDD depends on the sufficient water availability similarly to the one observed in coffee plants (Coffea arabica L.) (Petek et al. 2009). Analyzing the seed production from three locations in different years, it was verified that the greater physiological quality of E. pyriformis seeds would be obtained in an approximately 45day cycle if about 500 GDD were accumulated without water deficit and under a temperature range higher than $12^{\circ} \mathrm{C}$. Moreover it can be reported that the variations of the environmental hydric and thermal conditions and of Eugenia pyriformis fruit formation period influence seed maturation and dispersal moment, determining the cycle duration and final quality of these seeds.

\section{ACKNOWLEDGMENTS}

The authors thank Dr. Danilo da Cruz Centeno (UFABC), Dr. Edvaldo Aparecido Amaral da Silva (UNESP) and Dr. Gabriel Constantino Blain (IAC) for the suggestions and collaboration to the study; Dr. Lucia Rossi (IBt) for the species identification; Instituto de Botânica de São Paulo, São Paulo, SP; Instituto Agronômico de Campinas, Campinas, SP; Universidade Federal de Lavras, Lavras, MG; and Instituto Astronômico e Geofísico da Universidade de São Paulo, São Paulo, SP, for the concession of meteorological data; Conselho Nacional de Desenvolvimento Científico e Tecnológico (CNPq) for the fellwoships granted to E.V. Lamarca (PhD Course), J.S. Pratavieira (Scientific Initiation), M.B.P. Camargo, J.M.R. Faria and C.J. Barbedo (research productivity) and for the financial support to the project (Proc.477640/2009-5); Fundação de Amparo à Pesquisa do Estado de São Paulo (FAPESP) for the financial support to the project (Proc. 2005/04139-7)

\section{RESUMO}

O presente estudo tem como objetivo analisar a maturação e a dispersão de sementes de Eugenia pyriformis Cambess. produzidas em diferentes anos, verificando a influência das variações hídricas e térmicas do ambiente sobre suas características físicas e fisiológicas no momento em que são dispersas. Frutos com diferentes estágios de desenvolvimento foram coletados da região de São Paulo, entre 2003 e 2010 e das regiões de Campinas e Lavras, em 2009 e 2010 e foram analisados quanto ao tamanho e à cor. As sementes foram extraídas dos frutos e analisadas quanto ao conteúdo de massa seca, teor de água, germinação e vigor. Os resultados evidenciaram que a maturação das sementes ocorre de forma dessincronizada à maturação dos frutos, levando em média 45 dias (430 graus-dia), sendo mais demorada em períodos chuvosos ou de temperaturas mais baixas. Sementes de qualidade fisiológica mais elevada foram produzidas em anos chuvosos e quando a amplitude térmica foi maior. Conclui-se, portanto, que as variações hídricas e térmicas do ambiente e do período de formação influenciam sobre a maturação das sementes de uvaieira podendo, inclusive, determinar o ciclo de formação e a qualidade final dessas sementes.

Palavras-chave: dispersão, desenvolvimento, grausdia, precipitação pluvial, sementes recalcitrantes.

\section{REFERENCES}

ANDRADE RNB AND FERREIRA AG. 2000. Germinação e armazenamento de sementes de uvaia (Eugenia pyriformis Camb.) - Myrtaceae. Rev Bras Sementes 22: 118-125.

Avila AL, ARgenta MS, Muniz MFB, Poleto I and Blume E. 2009. Maturação fisiológica e coleta de sementes de Eugenia uniflora L. (pitanga), Santa Maria, RS. Ci Fl 19: 61-68. 
Barbedo CJ, Kohama S, Maluf AM and Bilia DAC. 1998. Germinação e armazenamento de diásporos de cerejeira (Eugenia involucrata DC. - Myrtaceae) em função do teor de água. Rev Bras Sementes 20: 184-188.

Borges KCF, Santana DG, Melo B and Santos CM. 2010. Rendimento de polpa e morfometria de frutos e sementes de pitangueira-do-cerrado. Rev Bras Frutic 32: 471-478.

BRASIL. 2009. Ministério da agricultura, pecuária e abastecimento. Regras para Análise de Sementes. Brasília, 399 p.

BRAZ MIG AND MatTos EA. 2010. Seed dispersal phenology and germination characteristics of a drought-prone vegetation in southeastern brazil. Biotropica 42: 327-335.

CAmargo AP And CAmargo MBP. 2001. Definição e esquematização das fases fenológicas do cafeeiro arábica nas condições tropicais do Brasil. Bragantia 60: 65-68.

CARDOSO GL AND LOMÔNACO C. 2003. Variações fenotípicas e potencial plástico de Eugenia calycina Cambess. (Myrtaceae) em uma área de transição cerrado-vereda. Rev Bras Bot 26: 131-140.

Daws Mi, Cleland H, Chmielarz P, Gorin F, Leprince O, Matthews S, Mullins CE, Thanos CA, VAndviK V AND PRITCHARD HW. 2006. Variable dessication tolerance in Acer pseudoplatanus seeds in relation to developmental conditions: a case of phenotypic recalcitrance? Funct Plant Biol 33: 59-66.

DAWs MI AND JENSEN M. 2011. Effects of developmental heat sum on fruit traits of clonal lines of Quercus petraea grown under controlled conditions. Plant Growth Regul 64: 203-206.

Daws Mi, Lydall E, Chmielarz P, Leprince O, Matthews S, THANOS CA AND PRITCHARD HW. 2004. Developmental heat sum influences recalcitrant seed traits in Aesculus hippocastanum across Europe. New Phytol 162: 157-166.

DELGADO LF AND BARBEDO CJ. 2007. Tolerância à dessecação de sementes de espécies de Eugenia. Pesq Agropec Bras 42: 265-272.

FAGUNDES JD, STRECK NA, StORCK L AND REINIGER LRS. 2010. Temperatura-base e soma térmica de subperíodos do desenvolvimento de Aspilia montevidensis. Bragantia 69: 499-507.

ISTA - InTERnational Rules For SeEd Testing. 1985. Seed Sci Techonol 13: 356-513.

Lamarca EV, Silva CV AND Barbedo CJ. 2011. Limites térmicos para a germinação em função da origem de sementes de espécies de Eugenia (Myrtaceae) nativas do Brasil. Acta Bot Bras 25: 293-300.

LeIVAs JF, Berlato MA AND FontanA DC. 2006. Risco de deficiência hídrica decendial na metade sul do Estado do Rio Grande do Sul. Rev Bras Eng Agric Ambient 10: 397-407.

MAGUIRE JD. 1962. Speed of germination-aid in selection and evaluation for seedling emergence and vigor. Crop Sci 2: 176-177.

Martins CC, Bovi MLA, Nakagawa J AND Machado CG. 2009. Secagem e armazenamento de sementes de juçara. Rev Árvore 33: 635-642.
Oliveira ENA, SANTOS DC, Sousa FC, Martins JN AND OLIVEIRA SPA. 2010. Obtenção de ubaia desidratada pelo processo de liofilização. Rev Bras. Tecnol Agroindustrial 4: 235-242.

Pedro Junior MJ, Brunini O, Alfonsi R And Angelocci LR. 1977. Estimativa de graus-dia em função de altitude e latitude para o estado de São Paulo. Bragantia 36: 89-92.

Pereira AR, Angelocci LR AND Sentelhas PC. 2002. Agrometeorologia: fundamentos e aplicações práticas. Livraria e Editora Agropecuária. Guaíba, RS, 478 p.

Petek MR, Sera T AND FonseCA ICB. 2009. Exigências climáticas para o desenvolvimento e maturação dos frutos de cultivares de Coffea arábica. Bragantia 68: 169-181.

Pezzopane JRM, Pedro-Junior MJ, Thomaziello RA AND CAMARGO MBP. 2003. Escala para a avaliação de estádios fenológicos do cafeeiro arábica. Bragantia 62: 499-505.

Pio R, GontiJo TCA, RAMOs JD AND ChALFUn NNJ. 2005. Características físico-químicas de frutos de pitangueira em função da altura de inserção na planta. Rev Bras Agrociênc 11: 105-107.

REUTHER W. 1977. Citrus. In: ALVIM PT and KOZLOWSKI TT (Eds), Ecophysiology of tropical crops, London: Academic Press, p. 409-439.

RIBEIRO RV, MACHADO EC AND BRUNINI O. 2006. Ocorrência de condições ambientais para a indução do florescimento de laranjeiras no estado de São Paulo. Rev Bras Frutic 28: 247-253.

Rolim GS, CAMARgo MBP, LANia DG AND Moraes JFL. 2007. Classificação climática de Köppen e de Thornthwaite e sua aplicabilidade na determinação de zonas agroclimáticas para o estado de São Paulo. Bragantia 66: 711-720.

SANTANA DG AND RANAL MA. 2004. Análise da germinação: um enfoque estatístico. Universidade de Brasília. Brasília, DF, $248 \mathrm{p}$.

SILVA RSM, CHAVES LJC AND NAVES RV. 2001. Caracterização de frutos e árvores de cagaita (Eugenia dysenterica dc.) no sudeste do estado de Goiás, Brasil. Rev Bras Frutic 23: 330-334.

Souza GM, Ribeiro RV, SANTOS MG, Ribeiro HL AND OliVEIRA RF. 2004. Approximate Entropy as a measure of complexity in sap flow temporal dynamics of two tropical tree species under water deficit. An Acad Bras Cienc 76: 625-630.

Thornthwaite CW AND MATHER JR. 1955. The water balance. Drexel Institute of Technology. (Publications in climatology). New Jersey, $104 \mathrm{p}$.

Villa Nova NA, Pedro Júnior MJ, Pereira AR AND OMETTO JC. 1972. Estimativa de graus-dia acumulados acima de qualquer temperatura base em função das temperaturas máxima e mínima. Cad Ciênc Terr 30: 1-8.

VOLPE CA, SCHÖFFEL ER AND BARBOSA JC. 2002. Influência da soma térmica e da chuva durante o desenvolvimento de laranjas-'valência' e 'natal' na relação entre sólidos solúveis e acidez e no índice tecnológico do suco. Rev Bras Frutic 24: 436-441. 